\title{
The 2007 flood in the Sahel: causes, characteristics and its presentation in the media and FEWS NET
}

\author{
C. Samimi ${ }^{1}$, A. H. Fink ${ }^{2}$, and H. Paeth ${ }^{3}$ \\ ${ }^{1}$ Department of Geography and Regional Research, University of Vienna, Austria \\ ${ }^{2}$ Institute of Geophysics and Meteorology, University of Cologne, Germany \\ ${ }^{3}$ Institute of Geography, University of Würzburg, Germany \\ Correspondence to: C. Samimi (cyrus.samimi@univie.ac.at)
}

Received: 6 June 2011 - Revised: 10 November 2011 - Accepted: 3 December 2011 - Published: 13 February 2012

\begin{abstract}
During the rainy season in 2007, reports about exceptional rains and floodings in the Sahel were published in the media, especially in August and September. Institutions and organizations like the World Food Programme (WFP) and FEWS NET put the events on the agenda and released alerts and requested help. The partly controversial picture was that most of the Sahel faced a crisis caused by widespread floodings. Our study shows that the rainy season in 2007 was exceptional with regard to rainfall amount and return periods. In many areas the event had a return period between 1 and $50 \mathrm{yr}$ with high spatial heterogeneity, with the exception of the Upper Volta basin, which yielded return periods of up to $1200 \mathrm{yr}$. Despite the strong rainfall, the interpretation of satellite images show that the floods were mainly confined to lakes and river beds. However, the study also proves the difficulties in assessing the meteorological processes and the demarcation of flooded areas in satellite images without ground truthing. These facts and the somewhat vague and controversial reports in the media and FEWS NET demonstrate that it is crucial to thoroughly analyze such events at a regional and local scale involving the local population.
\end{abstract}

\section{Introduction}

\subsection{Climate, floods and livelihoods in the Sahel}

The first reports about anomalies in the patterns of the monsoon rainfall in West Africa in 2007 were published by newspapers, magazines and news agencies in June. The news intensified in August and especially in September when major floods in the Sahel were reported and international aid agencies like the World Food Programme (WFP) started aid/relief campaigns and operations (e.g. BBC, 2007a; Ross, 2007; Thomson, 2007). Observing the news, it seemed like the whole Sahel was flooded by an extraordinary event, while normally droughts are associated with this region and have been emphasized more in the news as well as in the scientific literature (Nicholson, 2001). Nevertheless, the overall precipitation patterns in the Sahel are characterized by a high spatio-temporal variability, and so droughts and floods occur frequently on interannual and decadal scales (e.g. Paeth, 2004; Tarhule, 2005). Variability has become even more frequent and extreme after the late 1980s (Dai et al., 2004). Studies about climate change in West Africa suggest an even higher variability (e.g. Christensen et al., 2007, p. 871). Additionally, possible changes in rainfall patterns with an increase along the Guinean coast and a decrease in the Sahel are debated (Camberlin et al., 2001; Hulme et al., 2001; Milly et al., 2002; Paeth, 2004; Paeth and Hense, 2004; Paeth et al., 2009, Vigaud et al., 2011). However, it should be stressed that according to the 21 models used in the IPCC 4th Assessment Report, the evolution of rainfall in West Africa is presently fairly uncertain (Christensen et al., 2007, Joly et al., 2007) and hence the claimed increase in variability could also be uncertain.

Agriculture, cropping and livestock production are an important part of the economy in all West African countries. The livelihoods of large parts of the population are based on agriculture (UNDP, 2003). The people have developed strategies of adaptation and mitigation to cope with climate variability, practicing agriculture under the given climatic conditions for generations (Nyong et al., 2007). Nevertheless, droughts and floods have caused economic loss and hunger (Benson and Clay, 1998) and models of future agricultural productivity are not very promising (Paeth et al., 2008). 
Taking the above situation into consideration it is clear why many institutions focus on the Sahel and West Africa; e.g. the World Food Programme (WFP) is currently working in 42 African countries of which 16 are in West Africa (WFP, 2009). The US-AID-funded Famine Early Warning Systems Network (FEWS NET) is operating in six West African countries and publishes frequent reports about food security (FEWS NET, 2009a). Based on these data, "FEWS NET uses a suite of communication and decision support products to help decision makers act to mitigate food insecurity" (FEWS NET, 2009b). The Comité permanent Inter-Etats de Lutte contre la Sécheresse dans le Sahel (CILSS) operates the regional center CILSS/AGRHYMET (AGRHYMET Regional Centre, 2010a) which has a similar agenda as FEWS NET, with a focus on the Sahelian countries in West Africa (Mauritania, Senegal, The Gambia, Guinea-Bissau, Mali, Burkina Faso, Niger, and Chad).

The study only has a focus on the year 2007 because despite heavy rainfall, especially in 2009 and 2010, there were only three reports about floodings on BBC for the years 2008 to 2011 (BBC, 2008; BBC, 2009a; BBC, 2009b) and four in Reuters. So the media coverage was scarce compared to 2007.

\subsection{Climatology of the West African Monsoon}

As discussed before, the high spatio-temporal variability in rainfall is a crucial factor of land use in Sub-Saharan West Africa. The precipitation is related to the seasonal movement of the Intertropical Convergence Zone (ITCZ). It moves northward during boreal summer with a maximum northward extent at about $20^{\circ} \mathrm{N}$. During winter the ITCZ is located along the Gulf of Guinea coast. In West Africa the ITCZ marks the convergence zone of moist monsoonal air masses originating from the St. Helena anticyclone system and dry, north-east trade winds originating from the North African subtropical high. Other authors (e.g. Fink et al., 2010) consider the region of maximum tropospheric water vapor convergence and rainfall as the West African ITCZ location. The northward progression of the ITCZ or monsoon trough is often interrupted or even temporarily reversed, causing monsoon breaks. Additionally, it fluctuates diurnally by about $200 \mathrm{~km}$.

During the northern summer the surface airflow is capped by two easterly jets, the African Easterly Jet (AEJ) at about 700 to $500 \mathrm{hPa}(3000-5000 \mathrm{~m})$ and the Tropical Easterly Jet (TEJ) at about 200 to $100 \mathrm{hPa}(12400-16500 \mathrm{~m})$. The rainfall patterns in West Africa are determined by the position of the monsoon trough, the strengths and latitudinal positions of the easterly jets, and the development of African easterly waves (AEW) along the AEJ (e.g. Nicholson, 2008, 2009). Thus, the complex dynamic interactions between the surface airflows, the two easterly jets, and the AEWs control the rainfall patterns in West Africa. These processes are elaborately described by e.g. Hastenrath (1988) and Leroux (2001).
Although the principal processes of the West African monsoon are well understood, the precise causes for variations in the fluctuations of the monsoon trough, the exact role and dynamics of the AEJ and especially the related squall lines are still somewhat debated (e.g. Camberlin et al., 2001; Fall et al., 2006; Hulme et al., 2001; Janicot et al., 2001; Jenkins et al., 2002; Lélé and Lamb, 2010, Moron et al., 2008; Nicholson, 2008; Paeth and Thamm, 2007).

Similarly, many studies debate the influence of sea surface temperatures (SST) and the El Nino-Southern Oscillation (ENSO) on the rainfall distribution in West Africa (e.g. Camberlin et al., 2001; Hastenrath, 1992; Hirst and Hastenrath, 1983; Ward, 1998). But, Janicot et al. (2001) note that there is not a very clear link between ENSO events and Sahel rainfall. Therefore, they suggested a complex influence of ENSO-SSTs and global SSTs as a significant driver of Sahel rainfall, mainly the link between temperatures in the tropical northern Atlantic and in the tropical southern Atlantic. Additionally, SSTs in the eastern Mediterranean Sea and the Indian Ocean Sahel (Rowell, 2003; Bader and Latif, 2003) and land-surface-moisture feedbacks play an important role (Paeth and Thamm, 2007; Rowell et al., 1995).

Despite the extensive body of existing research, there is an urgent need to further understand the causes, especially in a region where the livelihoods of many people are directly dependent on rainfall. Predicting the seasonal variability of precipitation as well as modeling the effects of climate change on rainfall is vital (Friedrichs and Paeth, 2006; Held et al., 2005; Paeth et al., 2008). To fulfill these tasks, there are still knowledge gaps on how the different conditions of the ocean temperatures interact with land cover types and land cover change, especially on a regional and local scale.

\subsection{Objectives}

The objective of this study is to analyze to what extent the presentation of the 2007 flood in the news of online media and news portals of institutions (WFP etc.) reflects the real meteorological and flooding situation in West Africa. A special emphasis is put on online information from FEWS NET. The situation in 2007 is especially appropriate for the aim of the study as the discrepancy between media coverage and rainfall patterns was exceptional. The spatio-temporal characteristic and intensity of the rainfall has already been studied in a companion paper by Paeth et al. (2011). One main question addressed in Paeth et al. (2011) was whether the 2007 rainfall amount was exceptional. Additionally, the extent of the flooding is examined by MODIS images in a core area of the reported flood event. The results of Paeth et al. (2011) are summarized and used in this study to answer the question of whether the media reports and projections of institutions were adequate. 


\section{Data}

\subsection{Climate and satellite data}

For large parts of Africa, meteorological observations through climate stations are very sparse and therefore indirect estimations based on satellite data were used for a spatial characterization of the rainfall situation in Paeth et al. (2011). To get an idea about data quality for the observational period, four different rainfall data sets were compared.

The bases of our gridded rainfall analysis are daily aggregated TRMM data in version 3B42 V6 with a resolution of $0.25^{\circ} \times 0.25^{\circ}$ (Huffmann et al., 2007). The TRMM data were compared with the gauge-only GPCC data in a $0.5^{\circ}$ resolution (Rudolf, 1995) and the blended satellitegauge GPCP product on a $2.5^{\circ}$ grid (Adler et al., 2003) in Paeth et al. (2011). The authors showed that the interdata base consistency is high (up to 70-95\% common variance) in most parts of West Africa, especially in Burkina Faso and Ghana, two focal countries of this study. For the year 2007, the TRMM rainfall data were visually compared with data of rain gauges additionally. Except for parts of Nigeria and Ethiopia, the data sets show a satisfactory agreement and rainfall anomalies may be captured with comparable accuracy by ground-based and satellite-derived observations (Paeth et al., 2011). The comparison of the data showed that TRMM provides a reliable data basis in West Africa. An in-depth discussion is given in Paeth et al. (2011). TRMM- based data were also successfully applied for modeling floods in East Africa (Li et al., 2009).

In contrast to FEWS NET, we did not use "Rainfall Estimates" (RFE2.0) in Paeth et al. (2011) because they are discussed as not representing rainfall in an adequate manner, mainly underestimating precipitation (Dinku et al., 2007). A comparison of RFE2.0 and TRMM data for the rainy season 2007 proves the facts for many parts in West Africa (Fig. 1). Mainly along the West African coast, RFE2.0 drastically underestimates precipitation compared with TRMM. But mainly in the Sahel RFE2.0 also overestimates rainfall. Parker et al. (2011) reviewed RFE2.0 better but also stated that version 2.0 has major improvements compared to version 1.0 but version 2.0 only starts in 2001 .

In addition to standard statistical methods, extreme value statistics were also calculated to assess the question whether the 2007 rainy season was exceptional within the last decade and to estimate the return period of the 2007 event. A generalized Pareto distribution (GPD) was used for accumulated 1-day up to 20-day rainfall. The GPD parameters were estimated by the method of L-moments. Because the length of the time series is short, a Monte Carlo resampling approach with 50 random samples was applied. All calculations are performed for each single pixel in the TRMM data set of 2007 for the month June, July, August and September and compared against the TRMM data sets for the same month from 1998-2007. Detailed discussions about the extreme value statistics that were used in this study can be found in Born et al. (2008), Paeth et al. (2011) and Paeth and Hense (2004).

The analysis of the atmospheric flow conditions is based on ERA-Interim reanalysis data and on the NOAA OLR product. The influence of the ocean temperatures was examined with SST data from Reynolds et al. (2002). As the TRMM data, the data with the highest resolution used in our study, have been produced since 1998, all climatologic data analysis was performed for the period from 1998-2007 (Paeth et al., 2011).

Four MODIS (MOD09GQ) images with a resolution of $250 \mathrm{~m} \times 250 \mathrm{~m}$ recorded on 16 September 2007 (during the peak of the flood) and on 30 October 2007 (after the flood), were mosaiced and used to determine the extent of the flood. Water detection was done by applying thresholds for the Normalized Difference Vegetation Index (NDVI) and the Infrared Band (IR) (Paeth et al., 2011).

\subsection{Media and FEWS NET}

After publication of the first online articles about heavy rainfall in the rainy season of 2007 in June 2007, we continuously observed online media until one month - November 2011 - after the final reports could be found. Then we searched again in December 2007 and January 2008 to find out if reports had been published. Only online media were selected because they have a broader audience than most print media. Online media made it also possible to have access to the sources after the event and as only well-established sources were selected, they are still accessible on the web. Most of the reports came from the Integrated Regional Information Networks (IRIN, 2011a). IRIN is an initiative of the UN Office for the Coordination of Humanitarian Affairs (IRIN, 2011a) and claims that the services are editorially independent from institutions and governments. Thus, IRIN does not produce any data but gathers reports and news and archives and distributes them on a website (IRIN, 2011b). BBC, AlertNet (provided by the Thomson Reuters Foundation, AlertNet, 2009), and Reuters were also important sources.

FEWS NET is a USAID-funded initiative which is active mainly in Africa. Outside Africa, FEWS NET is present in Afghanistan, Haiti and Guatemala. In Africa, the Sahel of West Africa, and East Africa including Mozambique, Zambia and Zimbabwe are the focus of the organization (FEWS NET, 2009a). The core mission of FEWS NET is "to provide timely and rigorous early warning and vulnerability information on emerging and evolving food security issues" (FEWS NET, 2009b). Therefore, monthly updated food security outlooks are provided which give short-term and medium-term prospects. An exact description of how the information is generated is not available on the website. It is simply mentioned that "FEWS NET uses the latest available assessment and monitoring data, as well as baseline and historical data, 

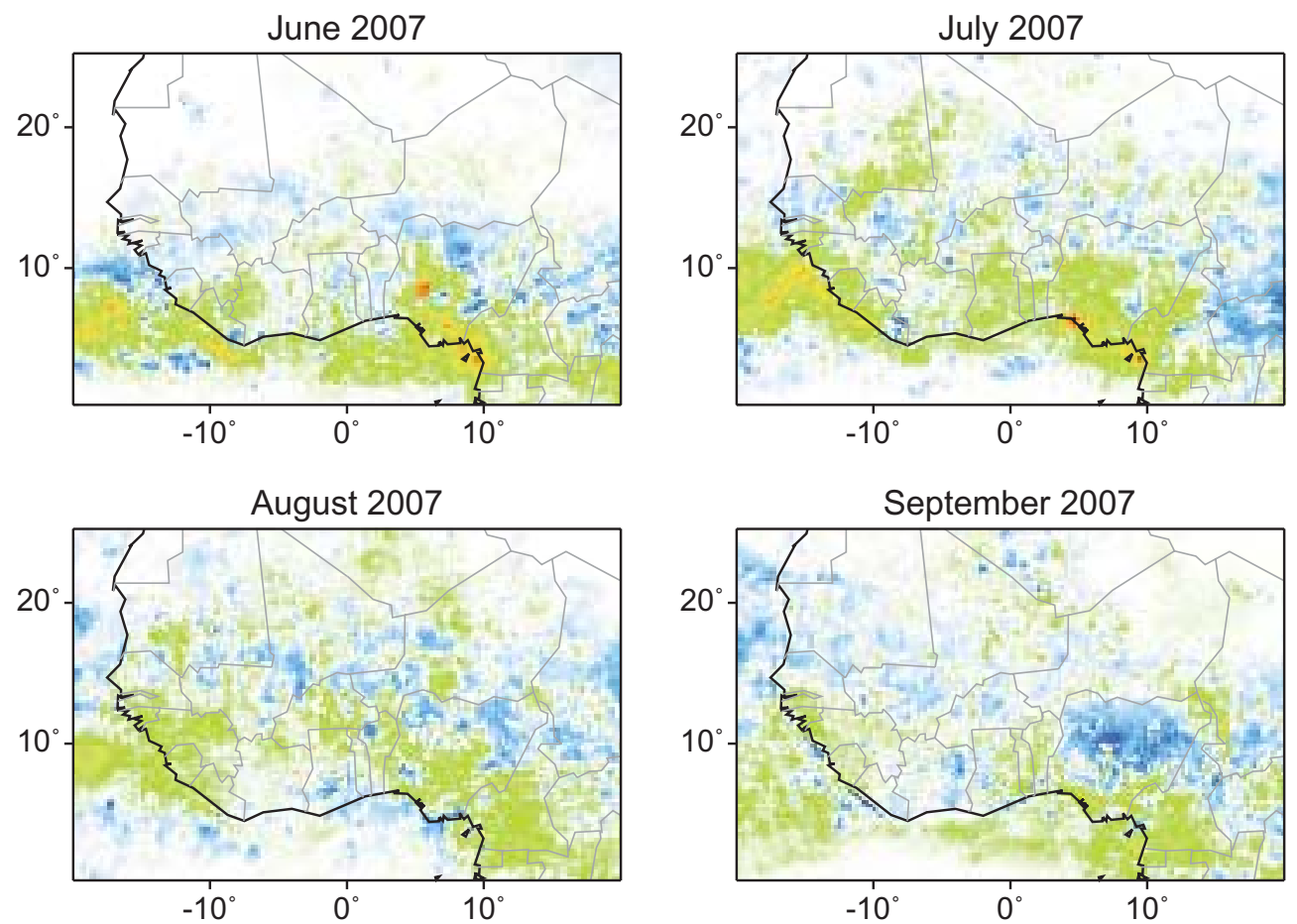

TRMM - RFE in $\mathrm{mm}$

\begin{tabular}{rrrrr}
-900 & -600 & -300 & 0 & 300 \\
\hline
\end{tabular}

Fig. 1. Differences between TRMM and RFA2.0 rainfall data for the rainy season 2007.
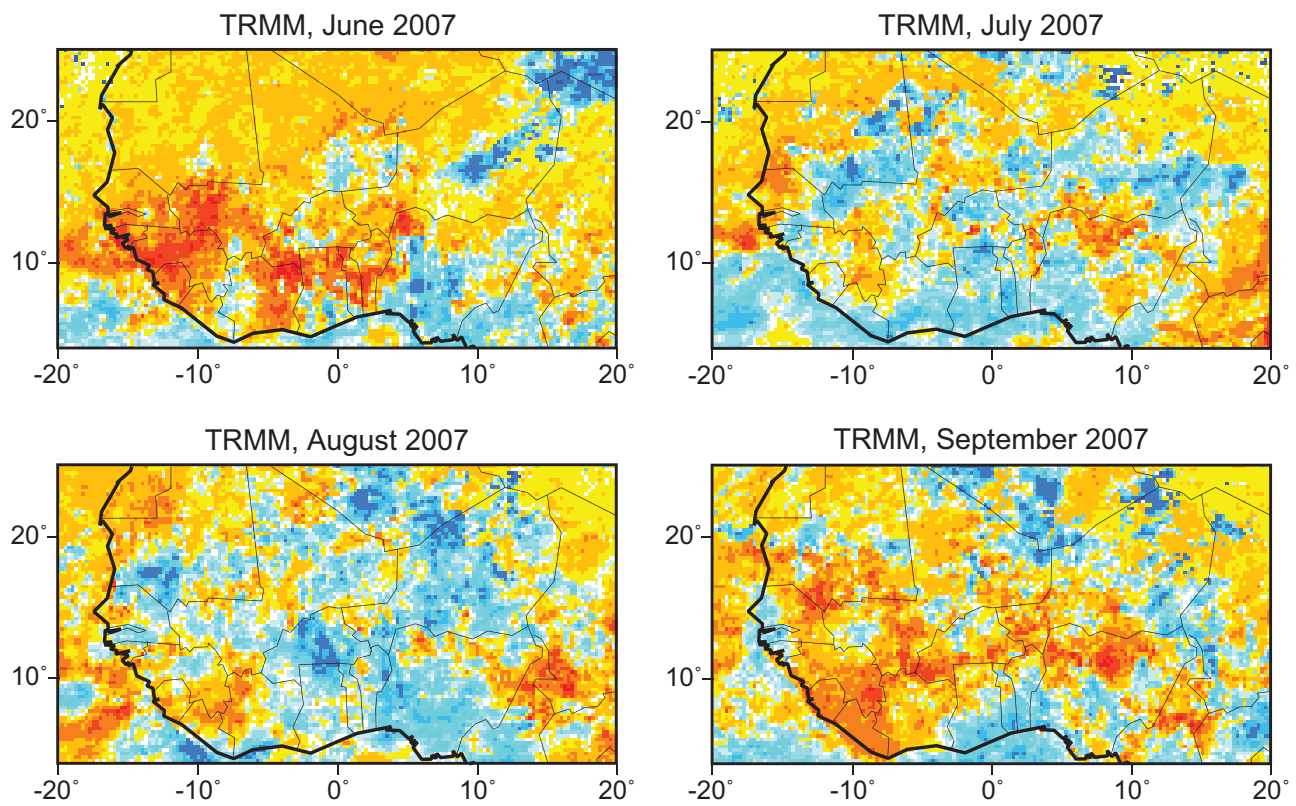

Standard deviation

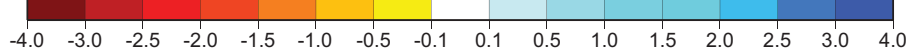

Fig. 2. Standardized precipitation anomalies from the 1998-2007 (based on Paeth et al., 2011). 
to conduct its analysis. A consensus-based process engaging relevant experts in each country is conducted to determine the appropriate level of food insecurity to assign to each area" (FEWS NET, 2009d). Another core product is the weekly updated Weather Impact Assessment which is provided in cooperation with the NOAA Climate Prediction Center (NOAA, CPC, 2006). No documents are provided on how the product is generated, but it seems that rainfall products such as Rainfall Estimates (RFE2.0) and NDVI products based on NOAA AVHRR, SPOT VGT and MODIS are combined (Love, 2004, Verdin et al., 2005). FEWS NET also publishes additional products, e.g. Livelihood Products, Market Reviews and Special Reports (FEWS NET, 2009c). AGRHYMET published monthly bulletins for June/July and August but not for September, and therefore is not included in our study (AGRHYMET Regional Centre, 2010b).

\section{Results and discussion}

\subsection{The meteorological characteristic of the rainy season and the flooding situation in $\mathbf{2 0 0 7}$}

\subsubsection{Meteorological characteristic}

In June the rainfall was below average in most of West Africa, except for parts of Nigeria, Cameroon, and Niger. Upon closer inspection, in southern Burkina Faso higher than average rainfall also occurred (Fig. 2). This is widely in accordance with the media reports (see Sect. 3.2). The early start of the rains might not be considered as the onset of the monsoon but as an isolated convective event. The start of the dynamic monsoon was late according to our studies (Paeth et al., 2011) which are based on Levinson and Lawrimore (2008, p. 111) who state: "As of July, rainfall was significant enough to offset the delayed onset of the monsoon, and flooding occurred in many areas, especially in Mali". Hence, in July the rains intensified and were above average in large parts of West Africa. Especially along the Guinean coast, exceptionally high rainfall was recorded with standard deviations of up to 2 (Fig. 2, top right). The positive precipitation anomalies reached the Sahel region with some drier areas mainly in Nigeria and Mali but also in Senegal and southern Mauritania. A very similar rainfall pattern can be observed in August before precipitation dropped below average in September. Mainly in southern Ghana, Togo and Benin, higher than average rainfall continued (Fig. 2). The rainfall shows a large spatial and temporal variation, typical for regions like West Africa with dominantly convective precipitation. The media reports correctly reflected the progression of the rainy season. However, it should be stressed that the media reports do not really describe the development of the rainy season but generally pick up out-of-the-ordinary situations in specific regions, created by the patchiness of the rainfall. These situations are then discussed as they represent much bigger regions up to the whole Sahel.

The estimation of the return times based on the TRMM data clearly shows that the 2007 rainy season was exceptional, with return periods between 1 and $200 \mathrm{yr}$ (Fig. 3, top left). Again, the pattern is very heterogeneous, grid boxes with a 200 year return period are beside boxes which fall below a $1 \mathrm{yr}$ return period (white areas in Fig. 3). However, some large areas are characterized by return periods longer than $10 \mathrm{yr}$ with a concentration in Burkina Faso, northern Ghana, and southern Nigeria. The accumulated rainfall for the identified extreme events of 4 to 16 days (Fig. 3, bottom left) in these regions exceeded $200 \mathrm{~mm}$ and reached up to $500 \mathrm{~mm}$ in Nigeria (Fig. 3, top right). The above-mentioned spatial heterogeneity of grid boxes with high rainfall and of those with low rainfall is typical for semiarid but also subhumid regions with dominantly convective precipitation. To address the question whether the whole Sahel, respectively, large parts of Sub-Saharan Africa were extremely wet in 2007, the estimated extreme values for daily precipitation were averaged for three regions (Paeth et al., 2011). SubSaharan Africa from $18^{\circ} \mathrm{W}-40^{\circ} \mathrm{E}$ and $0^{\circ} \mathrm{N}-20^{\circ} \mathrm{N}$ was not exceptional wet. The result is very different for West Africa $\left(3^{\circ} \mathrm{W}-15^{\circ} \mathrm{E}, 4^{\circ} \mathrm{N}-17^{\circ} \mathrm{N}\right)$ and the Upper Volta basin $\left(3^{\circ} \mathrm{W}-\right.$ $2^{\circ} \mathrm{E}, 10^{\circ} \mathrm{N}-15^{\circ} \mathrm{N}$ ), where the return period of the event was $100 \mathrm{yr}$ and even $600 \mathrm{up}$ to $1200 \mathrm{yr}$ for the latter region (Fig. 3).

The meteorological dynamics of the rainy season 2007 reflect the complex structure of the West African monsoon (see Sect. 1.2). The rainfall distribution over the Sahel in West Africa in 2007 can be characterized as a no-dipole wet situation according to Nicholson (2009) because high rainfall in the Sahel corresponded with high precipitation along the Guinean coast. The possible causes are extensively discussed by Paeth et al. (2011); the TEJ was significantly stronger than normal and was displaced southward. At the TEJ level, strong divergences caused an upward motion, probably enhancing the convection into large and intense mesoscale convective systems. The coupling with the dynamic feature of AEWs and convection was strong in the wet August of 2007. Additionally, the monsoon layer (i.e. the surface layer with monsoonal southwesterlies) was much deeper and stronger promoting the inland moisture transport from the Gulf of Guinea.

Major influences on rainfall in West Africa stem from SST conditions (see Sect. 1.2). In 2007, all oceans (with the possible exception of the Indian Ocean) with an influence on West Africa were in conditions favoring strong precipitation (Paeth et al., 2011). The tropical Atlantic was warmer than average throughout the northern summer, causing higher rainfall along the Guinean Coast. Normally, the Atlantic dipole with a warmer South than North Atlantic reduces precipitation in the Sahel north of $10^{\circ}$. This was only the case in September 2007, when the dipole intensified and the rains in the Sahel suddenly stopped. Additionally, the ENSO was in 

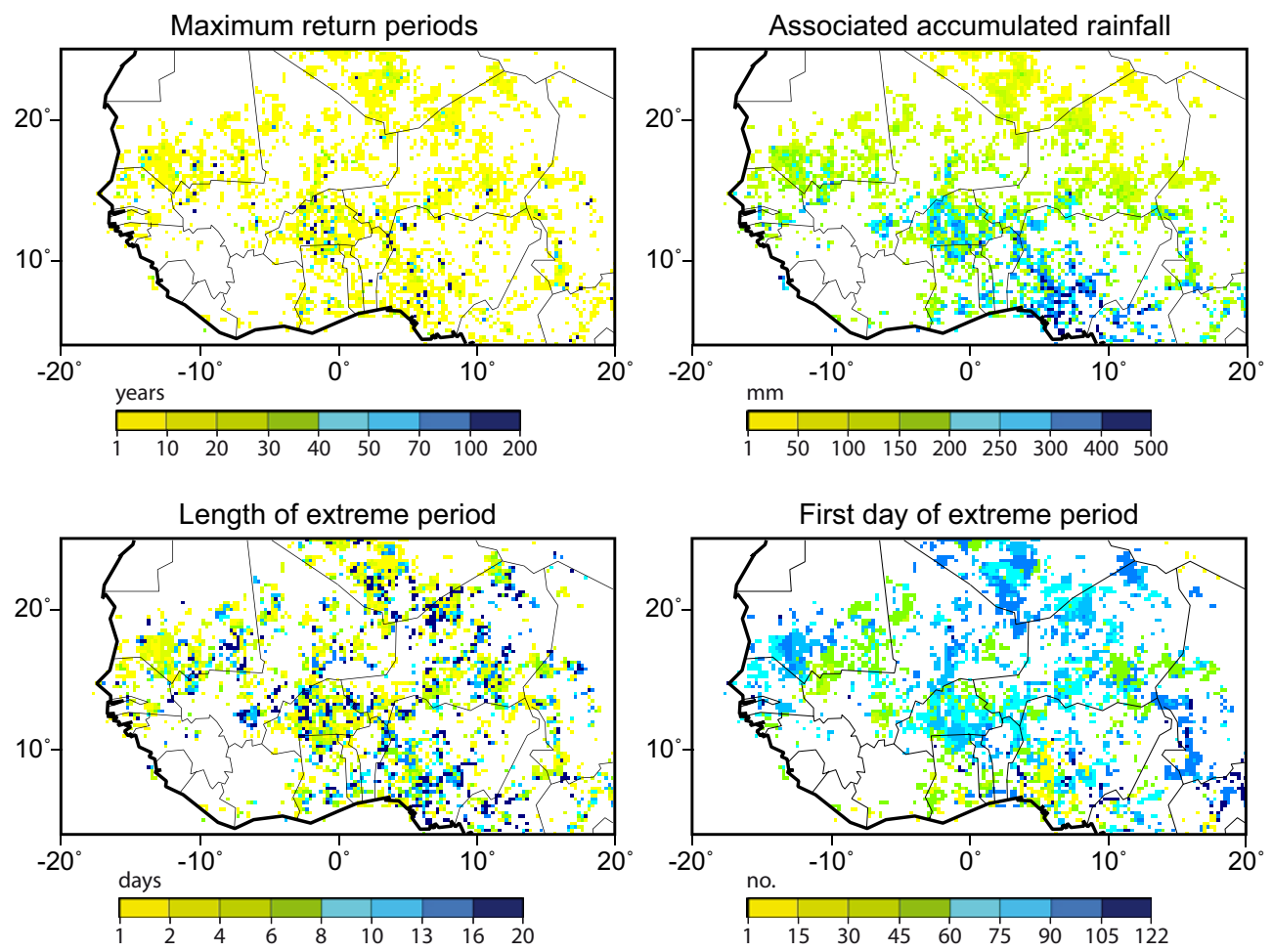

Fig. 3. Characterization of extreme rain events during JJAS 2007 (based on Paeth et al., 2011; see there for further explanations).

a La Niña state, also favoring precipitation (Nicholson et al., 2000). Moreover, the SSTs in the Mediterranean Sea were warmer than average, a situation that became recently known as being regularly associated with abundant rainfall across the Sahel (Rowell, 2003; Jung et al., 2006).

\subsubsection{Flooding situation}

As many weather impact assessments and food security studies are based on satellite images (see Sect. 2.1), the extent of flooding in the region was analyzed with MODIS data for a part of the Upper Volta catchment which was identified as a region with extreme rainfall (see Sect. 3.1.1; Paeth et al., 2011). The latter is corroborated by the accumulated rainfall totals (1 July to 10 September 2007) of $1200 \mathrm{~mm}$ and $1388 \mathrm{~mm}$ for Manga Bawku $\left(11^{\circ} 03^{\prime} \mathrm{N}\right.$; $0^{\circ} 14^{\prime} \mathrm{W}$, Ghana) and Zuarungu ( $10^{\circ} 47^{\prime} \mathrm{N} ; 0^{\circ} 51^{\prime} \mathrm{W}$, Ghana), respectively (G. Wilson, personal communication, Ghana Meteorological Agency, 2007). These stations are located in the White Volta Basin close to the border of Burkina Faso. Unfortunately, no long term records of these stations were available to us. Navrongo $\left(10^{\circ} 54^{\prime} \mathrm{N} ; 1^{\circ} 06^{\prime} \mathrm{W}\right.$, Ghana), about $30 \mathrm{~km}$ to the north-west of Zuarungu, recorded just $724 \mathrm{~mm}$ for the same period and $143 \%$ and $152 \%$ of the 19611990 July and August mean precipitation, respectively. Despite the heavy rainfall and the media reports, we could not identify area-wide floodings (Paeth et al., 2011). The high water levels identified by using a combination of thresholds based on the NDVI and the infrared channel (Sheng et al., 1998) are confined along the Volta and Lake Bagré with very low NDVI values, dropping below zero. These results are supported by maps published by the Dartmouth Flood Observatory (Dartmouth Flood Observatory, 2009). Just southeast of Pwalagu (Ghana) and north-east of Savelugu (Ghana) are areas with the probability of overland flooding probably caused by opening the dam of Lake Bagré (McCully, 2007). But even there the NDVI is well above 0.1 (Fig. 4). The post flooding image from 30 October shows much higher NDVIs in that region, so possibly the vegetation profited from high soil water contents after the surface water disappeared. The main problems identifying flooded areas especially during times of heavy rains and long standing water are suspended solid, dissolved organic matter and water plants, primarily shifting the peak of the reflectance from shorter wavelengths towards the red light (Cavalli et al., 2008). But the overall spectral characteristic remains constant and so it is still possible to determine water bodies through careful selection of thresholds (Paeth et al., 2011).

The overall impression of the vegetation conditions in September and at the end of October is good, with high to very high NDVI values. The values remain considerably high until the end of October which might be the result of good soil moisture conditions after the exceptional wet conditions during the rainy season. 


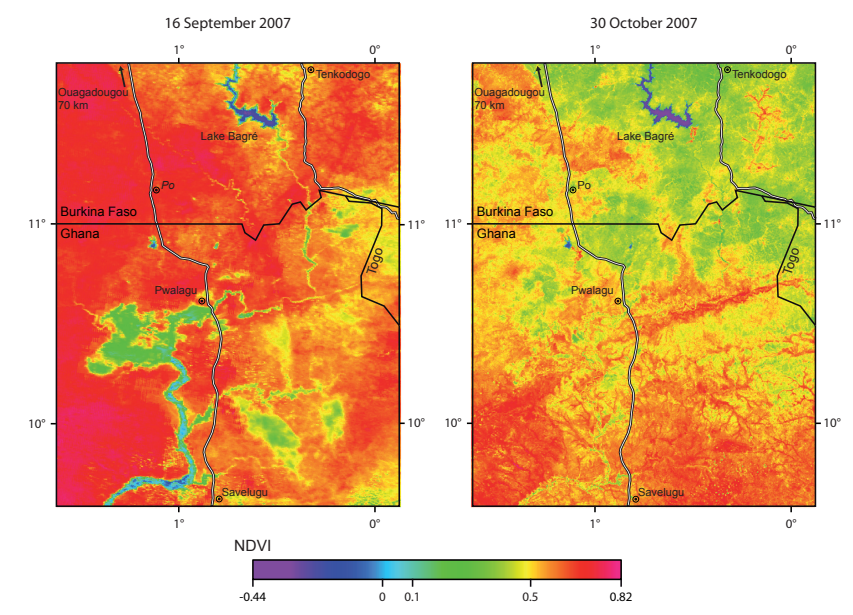

Fig. 4. NDVI along the White Volta basin in northern Ghana/southern Burkina Faso at 16 September and 30 October 2007 as derived from MODIS data (based on Paeth et al., 2011).

\subsection{The 2007 flood in the media}

The first report about the flooding was published on 21 June 2007 by IRIN (IRIN, 2007a). It reported premature rains for the Sahel region in early June and predicted erratically heavy rains. According to the report, which found its way straight into AlertNet (AlertNet, 2007), parts of Burkina Faso and Ghana were mainly affected. The next report was on 6 August by IRIN about floods in various parts of Nigeria (IRIN, 2007b). Then, news coverage intensified with around 13 articles in August and 14 in September. In October, just four articles were published in the beginning of the month and two at the end.

On 15 August Thomson wrote for Reuters that "downpours swept away food stocks, destroyed thousands of homes and killed well over 100 people across the Sahel, which stretches from Senegal on the Atlantic seaboard to Port Sudan on the Red Sea." (Thomson, 2007). According to the report, already 365000 people were affected and 50000 became homeless. The first article about Burkina Faso was published on 24 August (IRIN, 2007c), describing the situation to be worst in the north, west and east of the country, where altogether more than 10000 people were affected. Then Mali and Niger were in the media (IRIN, 2007d, e) before on 24 August heavy flooding was also reported in the south of Burkina Faso (IRIN, 2007f). According to this article strong rain fell on 10,17 and 20 August. Besides the fact that homeless people spend nights in schools from where they had to leave during the day, tensions between agriculturist and pastoralist were reported, resulting in at least 2000 displaced people and three deaths. Heavy rain occurred not only in the Sahel but also in Liberia, leaving 250000 people without piped water around Monrovia (IRIN, 2007g). On 4 September, Van Cotthem posted an article from
Dunkel on his blog which was distributed through Google Alert (Dunkel, 2007). Van Cotthem is a Honorary Professor at the University of Ghent (Belgium), which does not prevent him from posting a polemic article about the silence in the "imperialist media" and reporting that half a million people were victims of the flood. The number is in clear contrast to an article on 1 September by Reuters quoting the UN that 130000 were affected and that only Mauritania had requested international aid (Reuters, 2007a). One week later, Fominyen (2007) also wrote about more than half a million people being affected by the floods, also quoting the UN. At that time the WFP had already started to deliver food in Niger and Burkina Faso. The BBC picked up these news on 15 September and 17 September (BBC, 2007a, 2007b), in the latter article raising the number of victims to more than a million and 250 deaths. The region of northern Ghana and southern Burkina Faso was one of the main areas of the extreme event, with more than 300000 affected in northern Ghana (Reuters, 2007b). On the same day, 19 September, the WFP released an article in which it stated that the "United Nations World Food Programme (WFP) teams have fanned out across the region to distribute food to flood victims in several countries. WFP is working together with governments and other aid agencies to assess needs and respond swiftly, drawing on emergency stocks and bringing in helicopters and boats where necessary" (WFP, 2007a). The WFP urgently needed funds for operations and to continue feeding 300000 flood victims as well as refugees and displaced people for the next six months (WFP, 2007b). On 21 September Taneja (2007) asked somewhat less polemically than Dunkel (2007): "Are we ignoring Africa's floods?". She mainly blamed the media for not covering the event despite the huge impact on the people in large parts of Africa. At the end of her article she wrote: "Media attention is critical in emergencies such as this in raising awareness and mobilising an aid response", a statement also reflected in a report of the WFP (2007b) in which the WFP asked for funds and described its action in the flooded regions. In the first article after the flood, poor planning was identified to be one of the reasons for the problems (IRIN, 2007h). In the article, the local Mali Red Cross volunteer Bacari Keita is quoted: "Convince people not to build more houses in places historically prone to flooding. The town has already identified new sites where people can move to. The problem is that people are unwilling to think long term." In the last three articles, the need for long lasting aid was emphasized (IRIN, 2007i, j, k). According to these articles, the aid should last at least until June 2008 and they stated that after the flood, the rains stopped suddenly which might worsen the situation. Such a situation is described by Macamo (2003) for Mozambique, where in 2000 after a flood the rain stopped, causing a famine because the crops failed. 


\subsection{The 2007 flood in FEWS NET}

\subsubsection{Weather hazards impacts assessment}

The period 9-15 August was the first for which FEWS NET indicated flooding in West Africa - eastern Ghana, northern Benin, south-western Niger and north-western Nigeria (Fig. 5). The largest areas with flooding were in Sudan and Ethiopia, a region not covered in the present article. The regions in West Africa match with the reports in the media (see Sect. 3.2). For most of the Sahel, even for flooded areas, FEWS Net predicted "in season crop areas", which means that crops develop according to the growing season. Northern Ghana and northern Cote d'Ivoire were characterized by a "drought" combined with "somewhat favourable" conditions. This description did not change much until the end of September. Only the size of the region varied. This is in clear contrast to reports in the media and by WFP about floodings in northern Ghana (see Sect. 3.2). However, the heavy rainfalls were picked up in the description of the maps. Here, dry pre-season conditions were described which were followed by good to heavy rains. The flooded area disappeared during the next reports, and the flood then concentrated along the Niger and along the border of Nigeria and Cameroon, looking like a river. This linear flooding expanded into southern Nigeria and Western Cameroon and lasted until the end of September (Fig. 5). During the whole period, heavy rains were only mentioned for parts of Nigeria, Cameroon and Niger, which again is in total contrast to the reports in the media. The region for which "drought" and "somewhat favourable" conditions were mapped (northern Cote d'Ivoire, northern Ghana) did not change much in the reports after 16 August until the map for 20-26 September (Fig. 5). The explanatory text for the maps still described drought conditions with very localized heavy rain and flooding. For the period 20-26 September the text described the situation in northern Cote d'Ivoire as follows: "Côte d'Ivoire experienced poor rainfall at the onset of seasonal rains. Recent rains have the potential to improve crop and pasture conditions there, however many roads are now impassable due to flooding. Small localized regions of Burkina Faso have had similar conditions." (FEWS NET, 2007b). For Ghana it was stated that the dry conditions were eased by excessive rain causing local flooding with some damage to crops and infrastructure (FEWS NET, 2007b). The situation remained similar until the report for 11-17 October in which no flooded areas were mapped in West Africa (Fig. 5). Then, a band of "somewhat favourable" conditions stretched from the Atlantic coast to the east into Chad. The explanation for this area was: "Although flooding has damaged crops and infrastructure on a local scale in West Africa, the plentiful rainfall will likely lead to a third consecutive above normal harvest across the region. Rainfall is currently moving out of the area and flooding problems are giving way to more positive conditions." (FEWS NET, 2007c). During the whole

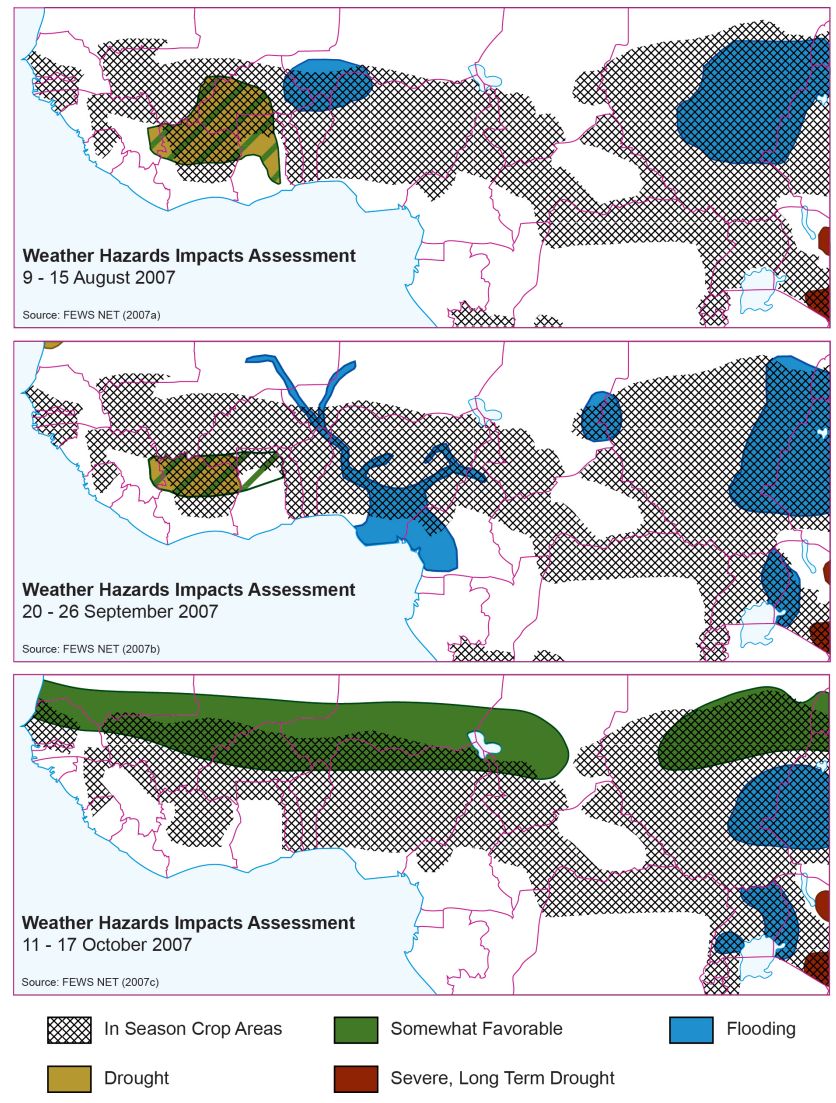

Fig. 5. FEWS NET - Weather Impacts Assessment for selected periods in 2007.

period from mid-July (12-18 July 2007) until the end of October (25-31 October 2007), most of the Sahel from the west to the east and further into Ethiopia was characterized as "In Season Crop Areas", even regions with drought and flooding (Fig. 5). Only the reporting period 2-8 August 2007 did not have this signature.

\subsubsection{Food security outlook}

No food security outlook for the region is available for the period of the heavy rains. After the rainy season an outlook was published, providing estimations for October until December 2007 and two scenarios until March 2008 (FEWS NET, 2007d, Fig. 6). The estimation showed that the Sahel and Nigeria was "generally food secure" after the good rains of the previous months. This seems to be in contrast to the media and the appraisement by WFP and IRIN (see Sect. 3.2). Additionally, the most likely scenario until March actually showed a "generally" or at least "moderately food insecure" situation. Just the worst case scenario predicted "extremely food insecure" conditions, mainly concentrated in northern Sahel. The comparison of different sources shows a discrepancy in the reports for the situation in 2007 which could cause uncoordinated aid. 

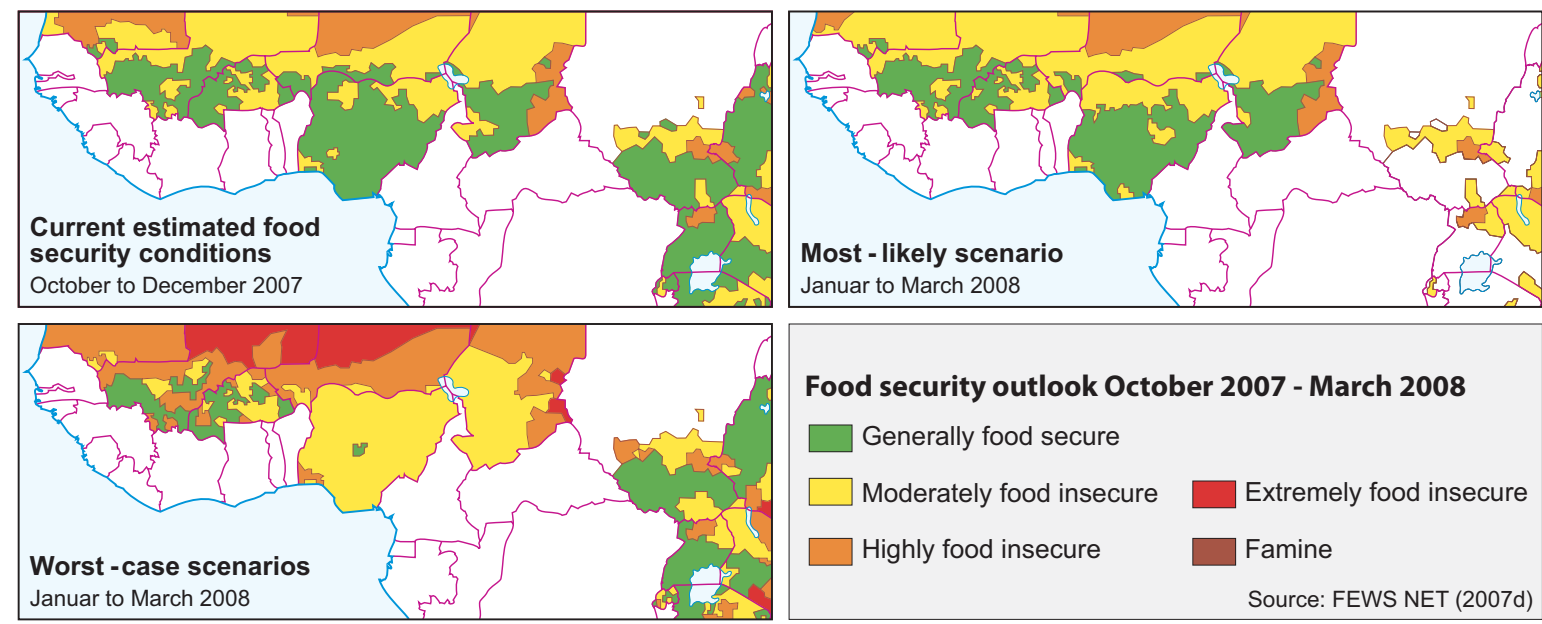

\section{Food security outlook October 2007 - March 2008 \\ Generally food secure \\ Moderately food insecure $\square$ Extremely food insecure \\ Highly food insecure $\square$ Famine Source: FEWS NET (2007d)}

Fig. 6. FEWS NET - Food Security Outlook from October 2007 until March 2008.

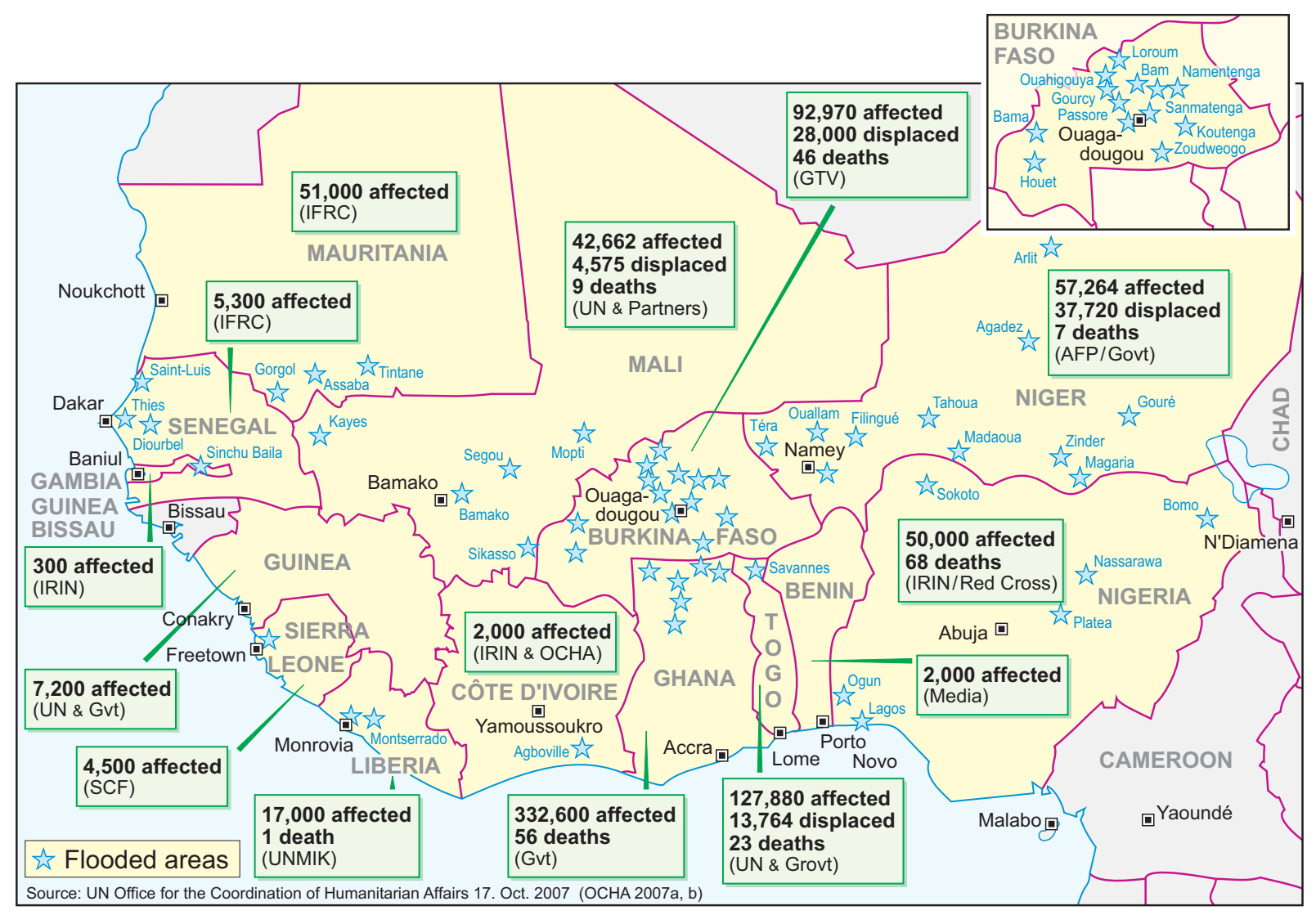

Fig. 7. Countries affected by the 2007 flood in West Africa (based on OCHA, 2007a, b).

\section{Conclusion and perspective}

The rainy season of 2007 was exceptional and caused widespread flooding affecting in total 792676 people in West Africa and causing 210 deaths (Fig. 7). Ghana was most affected, followed by Togo and Burkina Faso (OCHA, 2007a, b). But, as shown through the analysis of rainfall distribution and extent of the flooding by satellite images, it was not one event but many spatially and temporally highly heterogeneous events. However, it became obvious that an exact analysis of the weather phenomena and the spatial extent of the floods were problematic (Paeth et al., 2011). Despite the 
mission of FEWS NET to look at the country wide food security, not flood or weather, FEWS NET publishes Weather Impacts Assessments and Food Security Outlooks (FEWS NET, 2009a). But, it is quite doubtful if they provide a reliable source of information for emergency institutions as they are based on quick, standardized use of RFE and satellite products which are not well documented (see Sect. 2.1). This skepticism is supported by the very vague information on the flood situation and food security provided by these reports for the rainy season 2007 (see Sects. 3.2 and 3.3). A critique about FEWS NET was already formulated by Bohle (1992). So, FEWS Net should transparently explain the models for its projections and outlooks and make them more understandable, not only for research-oriented readers but also for decision makers and not just dissimilate messages/alerts without scientific explanation. The exclusive use of RFE2.0 should as well be questioned. Instead an ensemble of RFE2.0, TRMM and TAMSAT could be used, with TAMSAT even providing a resolution of $0.0375^{\circ} \times 0.0375^{\circ}$ (TAMSAT Research Group). Additionally, a real-time surface monitoring should support the rainfall products.

Nevertheless, support during emergencies is necessary but has to be carefully planned. For meaningful relief work, exact knowledge about the circumstances of food production and food security is crucial. The impact of aid in the wrong place and at the wrong time on local markets as well as on local livelihood strategies is well documented, e.g. Bohle (1992), Haas and Lohnert (1994), Macamo (2003), Watts (1989), Wisner et al. (2004).

Preliminary analyses indicate that severe floodings occurred in many parts of the western Sahel again in 2009 and 2010. They could serve as other cases to investigate the media representation and emergency response to floods in West Africa.

Summarized, especially in the context of global climate change, the consequences should be:

- to further understand the meteorological conditions and their relation with floodings;

- to improve models, predicting environmental events like flooding on a local and regional scale (Hong et al., 2007; Khan et al., 2011; Li et al., 2009; Wang et al., 2011) but by carefully using standard data products (Samimi et al., 2011);

- to carefully scrutinize information provided by modeled data sets and to validate them in the field;

- to carefully apply warning systems and emergency assessments because of the described complexity of the monsoon dynamics;

- to cautiously coordinate emergency assistance with respect to regional and local livelihood systems;
- to establish concepts for a locally organized information system for weather phenomena as described by Tarhule et al. (2009) could be a first step;

- institutions like the WFP and IRIN have the responsibility to sensibly publish news and should avoid giving a generalized picture where differentiated evidence is needed.

Acknowledgements. The authors express their gratitude to George Wilson, retired Acting Director General of the Ghana Meteorological Agency, for providing rainfall data from Ghana.

Edited by: U. Ulbrich

Reviewed by: two anonymous referees

\section{References}

Adler, R. F., Huffman, G. J., Chang, A., Ferraro, R., Xie, P.P., Janowiak, J., Rudolf, B., Schneider, U., Curtis, S., Bolvin, D., Gruber, A., Susskind, J., Arkin, P. A., and Nelkin, E.: The version-2 global precipitation climatology project (GCPC) monthly precipitation analysis (1979-present), J. Hydrometeorol. 4, 1147-1167, 2003.

Agrhymet Regional Centre: available at: http://www.agrhymet.ne/ eng/index.html, last access: April 2010a.

Agrhymet Regional Centre: Bulletins mensuels, available at: http: //www.agrhymet.ne/bulletin-mensuel.htm\#archives, (last access: April 2010b.

AlertNet: SAHEL: Flood season starts but not where it should, AlertNet, 21 June 2007, available at: http://www.alertnet.org/ thenews/newsdesk/IRIN/b2dd8f26040886b337dc37a5e3f9846a. htm (last access: October 2009), 2007.

AlertNet: AlertNet, available at: http://www.alertnet.org (last access: October 2009), 2009.

Bader, J. and Latif, M.: The impact of decadal-scale Indian Ocean sea surface temperature anomalies on Sahelian rainfall and the North Atlantic Oscillation, Geophys. Res. Lett., 30, CLM 7-1CLM 7-4, 2003.

BBC: Million hit by floods in Africa, BBC News, 17 September 2007, available at: http://news.bbc.co.uk/2/hi/africa/6998651. stm (last access: November 2011), 2007a.

BBC: Rains threaten flood-hit Africa, BBC News, 15 September 2007, available at: http://news.bbc.co.uk/2/hi/6994995.stm (last access: November 2011), 2007b.

BBC: UN call for Africa flood action, 9 September 2008, available at: http://news.bbc.co.uk/2/hi/africa/7605795.stm (last access: November 2011), 2008.

BBC: Many homeless in Burkina deluge, BBC News, 2 September 2009, available at: http://news.bbc.co.uk/2/hi/africa/8235040. stm (last access: November 2011), 2009a.

BBC: UN warns on West Africa floods, 5 September 2009, available at: http://news.bbc.co.uk/2/hi/africa/8239552.stm (last access: November 2011), 2009b.

Benson, C. and Clay, E. J.: The impact of drought on SubSaharan economies, World Bank Technical Paper, Washingthon DC, 1998.

Bohle, H.-G.: Hungerkrisen und Ernährungssicherung, Geograph. Rundschau, 44, 78-87, 1992. 
Born, K., Fink, A. H., and Paeth, H.: Dry and wet periods in the northwestern Maghreb for present day and future climate conditions, Meteorol. Z., 17, 533-551, 2008.

Camberlin, P., Janicot, S., and Poccard, I.: Seasonality and atmospheric dynamics of the teleconnection between African rainfall and tropical sea-surface temperature: Atlantic vs. ENSO, Int. J. Climatol., 21, 973-1005, 2001.

Cavalli, R. M., Laneve, G., Fusilli, L., Pignatti, S., and Santini, F.: Remote sensing water observation for supporting Lake Victoria weed management, J. Environ. Manage., 90, 2199-2211, 2008.

Christensen, J. H., Hewitson, B., Busuioc, A., Chen, A., Gao, X., Held, I., Jones, R., Kolli, R. K., Kwon, W.-T. , Laprise, R. , Magaña Rueda, V., Mearns, L., Menéndez, C.G., Räisänen, J., Rinke, A., Sarr, A., and Whetton, P.: Regional Climate Projections. in: Climate Change 2007: The Physical Science Basis, Contribution of Working Group I to the Fourth Assessment Report of the Intergovernmental Panel on Climate Change, edited by: Solomon, S., Qin, D., Manning, M., Chen, Z., Marquis, M., Averyt, K. B., Tignor, M., and Miller, H. L., Cambridge, New York, 847-940, SM.11-1-SM.11-46, 2007.

Dai, A., Lamb, P. J., Trenberth, K. E., Hulme, M., Jones, P. D., and Xie, P.: The recent Sahel drought is real, Int. J. Climatol., 24, 1323-1331, 2004.

Dartmouth Flood Observatory: Surface Water Data Record, available at: http://www.dartmouth.edu/ floods/Modis.html (lass access: April 2010), 2009.

Dinku, T., Ceccato, P., Grover-Kopec, E., Lemma, M., Connor, S. J., and Ropelewski, C. F.: Validation of satellite rainfall products over East Africa's complex topography, Int. J. Remote Sens., 28, 1503-1526, 2007.

Dunkel, G.: Imperialist media close their eyes as Floods devastate Africa's Sahel, available at:

http://desertification.wordpress.com/2007/09/04/

floods-devastate-africas-sahel-google-alert-workers-world (last access: October 2009), 2007.

Fall, S., Semazzi, F. H. M., Niyogi, D. D. S., Anyah, R. O., and Bowden, J.: The spatiotemporal climate variability over Senegal and its relationship to global climate and its relationship to global climate, Int. J. Climatol., 26, 2057-2076, 2006.

FEWS-NET: Weather Hazards Impacts Assessment for Africa August 9-15, 2007, available at: http://www.fews.net/docs/ Publications/1001376.pdf (last access: October 2009), 2007a.

FEWS-NET: Weather Hazards Impacts Assessment for Africa September 20-26, 2007, available at: http://www.fews.net/docs/ Publications/1001418.pdf (last access: October 2009), 2007b.

FEWS-NET: Weather Hazards Impacts Assessment for Africa October 11-17, 2007, available at: http://www.fews.net/docs/ Publications/1001437.pdf (last access: October 2009), 2007c.

FEWS-NET: Fews Net Food Security Outlook October 2007-March 2008, available at: http://www.fews.net/docs/ Publications/1001478.pdf (last access: October 2009), 2007d.

FEWS NET: Home, available at: http://www.fews.net/Pages/ default.aspx? $1=$ en, last access: October 2009a.

FEWS NET: About, What is FEWS NET?, available at: http: //www.fews.net/ml/en/info/Pages/default.aspx?l=en, last access: October 2009b.

FEWS NET: Product Catalogue, available at: http://www.fews. net/ml/en/product/Pages/default.aspx?l=en, last access: October 2009c.
FEWS NET: FEWS NET Food Insecurity Severity Scale, available at: http://www.fews.net/ml/en/info/pages/scale.aspx, last access: October 2009d.

Fink, A. H., Paeth, H., Ermert, V., Pohle, S., and Diederich, M.: Meteorological processes influencing the weather and climate of Benin, in: Impacts of Global Change on the Hydrological Cycle in West and Northwest Africa, edited by: Speth, P. and Christoph, M., Springer, Heidelberg, 135-149, 2010.

Fominyen, G.: West Africa flood toll revised to 159 dead: U.N. Reuters, 8 September 2007, available at: http://www.reuters. com/article/environmentNews/idUSTRE5874YU20090908 (last access: November 2011), 2007.

Friedrichs, P. and Paeth, H.: Seasonal prediction of African precipitation with ECHAM4-T42 ensemble simulations using a multivariate MOS re-calibration scheme, Clim. Dynam., 27, 761-786, 2006.

Hass, A. and Lohnert, B.: Ernährungssicherung in Mali, Geograph. Rundschau, 46, 554-560, 1994.

Hastenrath, S.: Climate and Circulation of the Tropics, Reidel, Dordrecht, 1988.

Hastenrath, S.: Global change: The signal in tropical ocean temperature and Sahel rainfall, Erdkunde, 46, 224-233, 1992.

Held, I. M., Delworth, T. L., Lu, J., Findell, K. L., and Knutson, T. R.: Simulation of Sahel drought in the 20th and 21st centuries, Proc. Nat. Aca. Sci., 102, 17891-17896, 2005.

Hirst, A. C. and Hastenrath, S.: Atmosphere-ocean mechanisms of climate anomalies in the Angola-tropical Atlantic sector, J. Phys. Ocean., 13, 1146-1157, 1983.

Hong, Y., Adler, R. F., Negri, A., and Huffman, G. J.: Flood and landslide applications of near real-time satellite rainfall estimation, J. Nat. Hazards, 43, 285-294, 2007.

Huffman, G. J., Adler, R .F., Bolvin, D. T., Gu, G., Nelkin, E. J., Bowman, K. P., Hong, Y., Stocker, E. F., and Wolff, D. B.: The TRMM multisatellite precipitation analysis (TMPA): Quasiglobal, multiyear, combined-sensor precipitation estimates at fine scales, J. Hydrometeorol., 8, 38-55, 2007.

Hulme, M., Doherty, R., Ngara, T., New, M., and Lister, D.: African climate change: 1900-2100, Clim. Res., 17, 145-168, 2001.

IRIN: SAHEL: Flood season starts but not where it should, IRIN, 21 June 2007, available at: http://www.irinnews.org/report.aspx? ReportId=72869 (last access: November 2011), 2007a.

IRIN: NIGERIA: Floods leave thousands homeless, IRIN, $6 \mathrm{Au}-$ gust 2007, available at: http://www.irinnews.org/Report.aspx? ReportId=73600 (last access: November 2011), $2007 \mathrm{~b}$.

IRIN: BURKINA FASO: Communities wiped out by countrywide flooding, IRIN, 13 August 2007, available at: http://www. irinnews.org/Report.aspx?ReportId=73708 (last access: October 2009), 2007c.

IRIN: MALI: Thousands of flood victims could be stranded when schools reopen, IRIN, 20 August 2007, available at: http://www. irinnews.org/Report.aspx?ReportId=73808 (last access: November 2011), 2007d.

IRIN: NIGER: Floods wreak havoc across the country, IRIN, 23 August 2007, available at: http://www.irinnews.org/Report aspx?ReportId=73902 (last access: November 2011), 2007e.

IRIN: BURKINA FASO: Flood devastation worsening, IRIN, 24 August 2007, available at: http://www.irinnews.org/Report. aspx?ReportId=73937 (last access: November 2011), $2007 \mathrm{f}$.

IRIN: LIBERIA: Floods displace hundreds in Monrovia, IRIN, 
27 August 2007, available at: http://www.irinnews.org/Report. aspx?ReportId=73973, (last access: November 2011), 2007g.

IRIN: MALI: Bad planning to blame for flood damage, IRIN, 1 October 2007, available at: http://www.irinnews.org/Report.aspx? ReportId=74573 (last access: November 2011), 2007h.

IRIN: BURKINA FASO: Local leaders say flood-hit residents will need food aid for months, IRIN, 4 October, available at: http://www.irinnews.org/Report.aspx?ReportId=74650 (last access: November 2011), $2007 i$.

IRIN: GHANA: Food shortages follow drought, floods, IRIN, 25 October 2007, available at: http://www.irinnews.org/Report. aspx?ReportId=74993 (last access: November 2011), 2007j.

IRIN: BURKINA FASO: UN needs \$6 million for urgent postflood recovery, IRIN, 29 October 2007, available at: http: //www.irinnews.org/Report.aspx?ReportId=75043, (last access: November 2011), 2007k.

IRIN: About IRIN, available at: http://www.irinnews.org/about. aspx, last access: January 2011a.

IRIN: available at: http://www.irinnews.org, last access: January $2011 b$.

Janicot, S., Trazaska, S., and Poccard, I.: Summer Sahel-ENSO teleconnection and decadal time scale SST variations, Clim. Dynam., 18, 303-320, 2001.

Jenkins, G. S., Adamou, G., and Fongang, S.: The challenges of modelling climate variability and change in West Africa, Climatic Change, 52, 263-286, 2002.

Joly, M., Voldoire, A., Douville, H., Terray, P., and Royer, J.-F.: African monsoon teleconnections with tropical SSTs: Validation and evolution in a set of IPCC4 simulations, Clim. Dynam., 29, 1-20, 2007.

Jung, T., Ferranti, L., and Tompkins, A. M.: Response to the summer of 2003 Mediterranean SST anomalies over Europe and Africa, J. Climate, 19, 5439-5454, 2006.

Khan, S. I., Hong, Y., Wang, J., Yilmaz, K. K., Gourley, J. J., Adler, R.F., Brakenridge, G. R., Policelli, F., Habib, S., and Irwin, D.: Satellite Remote Sensing and Hydrologic Modeling for Flood Inundation Mapping in Lake Victoria Basin: Implications for Hydrologic Prediction in Ungauged Basins, IEEE Trans. Geosci. Remote Sens., 49, 85-95, 2011.

Lélé, M. I. and Lamb, P. J.: Variability of the Intertropical Front (ITF) and rainfall over the West African Sudan-Sahel zone, J. Climate, 23, 3984-4004, 2010.

Leroux, M.: The Meteorology and Climate of Tropical Africa, Springer, London, 2001.

Levinson D. H. and Lawrimore, J. H. (Eds.): Climate assessment for 2007, B. Am. Meteorol. Soc., 89, 1-179, 2008.

Li, L., Hong, Y., Wang, J., Adler, R. F., Policelli, F. S., Habib, S. Irwn, D., Korme, T., and Okello, L.: Evaluation of the real-time TRMM-based multi-satellite precipitation analysis for an operational Flood Prediction System in Nzoia Basin, Lake Victoria, Africa, J. Nat. Hazards, 50, 109-123, 2009.

Love, T. B.: GIS enhancement of Climate Prediction Center's Africa FEWS-NET products, 20th International Conference on Interactive Information and Processing Systems (IIPS) for Meteorology, Oceanography, and Hydrology, American Meteorological Society, Seattle, USA, 12-15 January 2004, P2.47, available at: http://ams.confex.com/ams/84Annual/techprogram/ paper_67529.htm, (last access: January 2012), 2004.

Macamo, E.: Nach der Katastrophe ist die Katastrophe, Die 2000er
Überschwemmung in der dörflichen Wahrnehmung in Mosambik, in: Entsetzliche soziale Prozesse. Theorie und Empirie der Katastrophen, edited by: Clausen, L., Geenen, E. M., and Macamo, E., Lit, Münster, 167-184, 2003.

McCully, P.: Dams pose security risk to Africa, available at: http: //news.mongabay.com/2007/1004-irn.html (last access: May 2011), 2007.

Milly, P. C. D., Wetherald, R. T., Dunne, K. A., and Delworth, T. L.: Increasing risk of great floods in a changing climate, Nature, 415, 514-517, 2002.

Moron, V., Robertson, A. W., Ward, M. N., and Ndiaye, O.: Weather types and rainfall over Senegal. Part I: Observational analysis, J. Climate, 21, 266-287, 2008.

Nicholson, S. E.: Climatic and environmental change in Africa during the last two centuries, Clim. Res., 17, 123-144, 2001.

Nicholson, S. E.: The intensity, location and structure of the tropical rainbelt over West Africa as factors in interannual variability, Int. J. Climatol., 28, 1775-1785, 2008.

Nicholson, S. E.: On the factors modulating the intensity of the tropical rainbelt over West Africa, Int. J. Climatol., 29, 673-689, 2009.

Nicholson, S. E., Some, B., and Kone, B.: An analysis of recent rainfall conditions in West Africa, including the rainy seasons of the 1997 el Niño and the 1998 la Niña years, J. Climate, 13, 2628-2640, 2000.

NOAA, CPC: Africa meteorological products for the Famine Early Warning System Network (FEWS-NET), available at: http:// www.cpc.ncep.noaa.gov/products/fews/africa (last access: October 2009), 2006.

Nyong, A., Adesina, F., and Elasha, B. O.: The value of indigenous knowledge in climate change mitigation and adaptation strategies in the African Sahel, Mitigation and Adaptation Strategies for Global Change, 12, 787-797, 2007.

OCHA: West Africa - floods as of 27 Sep 2007, available at: http://reliefweb.int/sites/reliefweb.int/files/resources/ 2A3EBB3602FF36418525736400536822-ocha_FL_wa070927. pdf (last access: January 2012), 2007a.

OCHA: West Africa - Floods as of 17 October 07, available at: http://reliefweb.int/sites/reliefweb.int/files/resources/ FDBC0DD4783141E385257378004811DF-ocha_FL afr071017.pdf (last access: January 2012), 2007b.

Paeth, H.: Key factors in African climate change evaluated by a regional climate model, Erdkunde, 58, 290-315, 2004.

Paeth, H. and Hense, A.: SST versus climate change signals in West African rainfall: 20th-century variations and future projections, Climatic Change, 65, 179-208, 2004.

Paeth, H. and Thamm, H.-P.: Regional modelling of future African climate north of $15^{\circ} \mathrm{s}$ including greenhouse warming and land degradation, Climatic Change, 83, 401-427, 2007.

Paeth, H., Capo-Chichi, A., and Endlicher, W.: Climate Change and Food Security in Tropical West Africa - A Dynamic-Statistical Modelling Approach, Erdkunde, 62, 101-115, 2008.

Paeth, H., Born, K., Girmes, R., Podzun, R., and Jacob, D.: Regional climate change in tropical and Northern Africa due to greenhouse forcing and land use changes, J. Climate, 22, 114132, 2009.

Paeth, H., Fink, A. H., Pohle, S., Keis, F., Mächel, H., and Samimi, C.: The 2007 flood in sub-Saharan Africa: spatio-temporal characteristics and potential causes, Int. J. Climatol., 31, 1908-1926, 
2011.

Parker, D., Good, E., and Chadwick, R.: Reviews of Observational Data Available over Africa for Monitoring, Attribution and Forecast Evaluation, Hadley Centre Technical Note 86, available at: www.metoffice.gov.uk/media/pdf/b/o/HCTN_86_revised.pdf (last access: November 2011), 2011.

Reuters: More than 130,000 hit by floods in West Africa- UN, Reuters, 1 September 2007, available at: http://www.reuters. com/article/africaCrisis/idUSL01118339 (last access: November 2011), 2007a.

Reuters: RPT-FEATURE-African skies rain death, destruction on villagers, Reuters, 19 September 2007, available at: http://www. reuters.com/article/featuredCrisis/idUSL18803681 (last access: October 2009), 2007b.

Reynolds, R. W., Rayner, N. A., Smith, T. M., Stokes, D. C., and Wang, W.: An improved in situ and satellite SST analysis for climate, J. Climate, 15, 1609-1625, 2002.

Ross, W.: Floods devastate northern Ghana, BBC News, 15 September 2007, available at: http://news.bbc.co.uk/1/hi/world/ africa/6996584.stm (last access: November 2011), 2007.

Rowell, D. P.: The impact of Mediterranean SSTs on the Sahelian rainfall season, J. Climate, 16, 849-862, 2003.

Rowell, D. P., Folland, C. K., Maskell, K., and Ward, M. N.: Variability of summer rainfall over tropical North Africa (1906-92): Observations and modelling, Q. J. R. Meteorol. Soc., 121, 669704, 1995.

Rudolf, B.: The Global Precipitation Climatology Centre, WMO Bulletin, 44, 77-78, 1995.

Samimi, C., Le Roux, J., Wagenseil, H., and Kraus, T.: Quantifizierung von Ökosystemparametern in Afrika mit Satellitenfernerkundung. Möglichkeiten, Probleme und Limitierungen, in: Geographie für eine Welt im Wandel, 57. Deutscher Geographentag 2009 in Wien, edited by: Fassmann, H. and Glade, T., Wien, Vienna University Press, 399-414, 2011.

Sheng, Y., Su, Y., and Xiao, Q.: Challenging the cloudcontamination problem in flood monitoring with NOAA/AVHRR imagery, Photogramm. Eng. Rem. S., 64, 191-198, 1998.

TAMSAT Research Group: available at: http://www.met.reading. ac.uk/ tamsat/about, last access: May 2011.

Taneja, P.: Are we ignoring Africa's floods?, Reuters AlertNet, 21 September 2007, available at: http://www.alertnet.org/db/blogs/ 42444/2007/08/21-142512-1.htm (last access: October 2009), 2007.
Tarhule, A.: Damaging Rainfall and Flooding: The other Sahel Hazards, Climatic Change, 72, 355-377, 2005.

Tarhule, A., Saley-Bana, Z., and Lamb, P. bL.: Rainwatch. A Prototype GIS for Rainfall Monitoring in West Africa, B. Am. Meteorol. Soc., 90, 1607-1614, 2009.

Thomson, A.: Deadly floods, disease afflict Africa's arid Sahel, Reuters, 15 August 2007, available at: http://www.reuters. com/article/worldNews/idUSL1581162120070815 (last access: November 2011), 2007.

UNDP: Human Development Report 2003, Millennium Development Goals: A Compact Among Nations to End Human Poverty, New York, Oxford, 2003.

Verdin, J., Funk, C., Senay, G., and Choularton, R.: Climate science and famine early warning, Philos. T. R. So. B, 360, 2155-2168, 2005.

Vigaud, N., Roucou, P., Fontaine, B., Sijikumar, S., and Tyteca, S.: WRF/ARPEGE-CLIMAT simulated climate trends over West Africa, Clim. Dynam., 36, 925-944, 2011.

Wang. J., Hong, Y., Li, L., Gourley, J. J., Yilmaz, K., Khan, S. I., Policelli, F. S., Adler, R. F., Habib, S., Irwn, D., Limaye, S. A., Korme, T., and Okello, L. : The Coupled Routing and Excess STorage (CREST) distributed hydrological model, Hydrol. Sci. Jo., 56, 84-98, 2011.

Ward, M. N.: Diagnosis and short-lead time prediction of summer rainfall in tropical North Africa at interannual and multidecadal timescales, J. Climate, 11, 3167-3191, 1998.

Watts, M. J.: The agrarian question in Africa: Debating the crisis, Prog. Hum. Geog., 13, 1-41, 1989.

WFP: Floods across sub-Saharan Africa hit 1.5 million people, WFP News, 19 September 2007, available at: http://www.wfp. org/node/7818 (last access: November 2011), 2007a.

WFP: WFP seeks funds for flood operations across Africa, WFP News, 26 September 2007, available at:

http://www.wfp.org/news/news-release/

wfp-seeks-funds-flood-operations-across-africa (last access: November 2011), 2007b.

WFP: Countries, available at: http://www.wfp.org/countries (last access: October 2009), 2009.

Wisner, B., Blaikie, P., Cannon, T., and Davis, I.: At risk. Natural hazards, people's vulnerability and disasters, Routledge, London, New York, 2004. 